\title{
Detection and phylogenetic analysis of porcine epidemic diarrhea virus in central China based on the ORF3 gene and the S1 gene
}

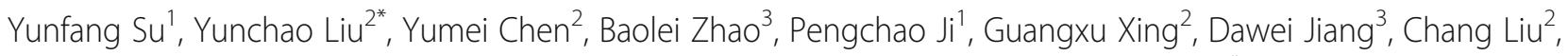
Yapeng Song ${ }^{3}$, Guoqiang Wang ${ }^{3}$, Dongliang $\mathrm{Li}^{3}$, Ruiguang Deng ${ }^{2}$ and Gaiping Zhang ${ }^{2,3,4^{*}}$

\begin{abstract}
Background: Porcine epidemic diarrhea (PED) has increased in severity in China since 2010. To investigate further the infectivity, genetic diversity and molecular epidemiology of its causative agent, the porcine epidemic diarrhea virus (PEDV), we assessed 129 clinical samples, which were the intestinal tissue of piglets with severe diarrhea, from 17 cities in central China. Both the spike (S) glycoprotein (S1, 1-789 amino acids (aa)) and the full-length ORF3 gene of 21 representative field strains from 21 farms in 11 cities were sequenced and analysed.

Methods: PEDV was detected by reverse transcription-polymerase chain reaction (RT-PCR), and S1 and ORF3 sequences were processed by the Clustal W method via DNAMAN 8 software, and phylogenetic trees were constructed by the neighbor-joining method using MEGA 6 software.

Results: The prevalence of PEDV was $92.25 \%$ and was detected in 119 of 129 samples, with $94.03 \%$ (63 of 67) of pig farms harbouring the disease. According to the phylogenetic analysis of the $\mathrm{S1}$ genes, our isolates all fell into group G2 (variants) and showed a close relationship to isolates from Chinese (HN1303, CH/ZMDZY/11 and AJ1102), Korean (AD01), American (MN, IA1, IA2 and 13-019349) sources, and these isolates differed genetically from other Chinese (LZC, CH/HNZZ/2011 and SD-M) and Korean (SM98) strains as well Japanese (83-P5 and MK) strains. In addition, our isolates differed from attenuated vaccine strains, CV777 (used in China) and DR13 (used in Korea). According to our derived amino acid sequence analysis, we detected one novel variant PEDV, viz: CH/HNLY, with 4-aa insertion/deletion (RSSS/T) at position 375 and 1-aa (D) deletion at position 430 compared to the CV777 attenuated strain. These mutations were located on the receptor binding domain. Our ORF3 gene analyses showed that the prevalent PEDV isolates were variants, and the isolated strains differed genetically from the vaccine strains.

Conclusions: These findings illustrated the existence of genetic diversity among geographically distinct PEDV strains, and our study has provided an impetus to conduct further research on the PEDV receptor binding protein and on the new and efficacious vaccines design.
\end{abstract}

Keywords: PEDV, ORF3 gene, S1 gene, Phylogenetic analysis, Variants

\footnotetext{
* Correspondence: yunchaoliu2012@163.com; zhanggaiping2003@163.com

${ }^{2}$ Henan Provincial Key Laboratory of Animal Immunology, Henan Academy

of Agricultural Science, Zhengzhou 450002, China

Full list of author information is available at the end of the article
} 


\section{Background}

Porcine epidemic diarrhoea (PED) is an acute, highly contagious disease of swine caused by the PED virus (PEDV), which leads to severe vomiting and diarrhea along with dehydration and high mortality in new-born piglets [1]. PEDV belongs to the family Coronaviridae, genus Alphacoronavirus and was first reported in England [2]. PEDV has now been reported worldwide, including in Belgium, France, Japan, Korea, Italy, Thailand, USA, Canada and Mexico [1-5] and poses severe economic burdens. Since 2010 serious PED has been detected in China [6]. PEDV is an enveloped ssRNA coronavirus with a $28 \mathrm{~kb}$ genome, including seven open reading frames (ORFs), a 5' untranslated region (UTR), and a 3' UTR with a polyadenylated tail. The seven ORFs encode four structural proteins, spike (S), envelope (E), membrane (M) and nucleocapsid $(\mathrm{N})$ and three non-structural proteins, replicases $1 \mathrm{a}, 1 \mathrm{~b}$ and ORF3 $[7,8]$. The $\mathrm{S}$ protein contains a specific receptor binding site that is important for cell membrane fusion and virus entry and is an antigenic target for neutralising antibodies [9]. The $M$ protein is the most abundant surface protein, and coexpression with $\mathrm{E}$ protein to form pseudo-particles results in interfering genic activity [10]. The $\mathrm{N}$ protein is highly conserved and binds to virion RNA to provide a structural basis for the helical nucleocapsid, and it is used for early diagnosis [11]. For non-structural proteins, replicases $1 \mathrm{a}$ and $1 \mathrm{~b}$ are multi-functional and associated with viral genome replication [12], and the accessory ORF3 protein is thought to influence virulence [13].

The S1 domain (amino acids (aa) 21-793) contains two subdomains: NTD (aa 21-324) and CTD (aa 253-638) [14], with the latter binding to porcine aminopeptidase $\mathrm{N}$ (pAPN) which is important for cell membrane fusion and virus entry and it is the antigenic target of neutralising antibodies [15]. Thus, the variable $\mathrm{S} 1$ gene has been widely used for studies of PEDV genetic evolution and diversity $[16,17]$. PEDV CV777 has three main neutralising epitopes: aa 498-637 (CO-26 K equivalent, COE gene) [18], aa 747-754 (YSNIGVCK) and aa 763-770 (LQDGQVKI) [19]. Sequence analyses indicated that the latest PEDV isolated strains in China were different from attenuated CV777 [16, 20, 21]. Multiple mutations of the S protein resulted in two PEDV genotypes, G1 and G2 (classical strains and variant strains) [16], and a recent study suggested that antigenic variation exists between G1 and G2 [22]. The variable S1 gene has been widely used for studies of PEDV genetic evolution and diversity [16, 17]. The accessory ORF3 gene is highly relevant to the virulence of PEDV as previously stated [13], and reduction in virulence is produced through cell culture adaptation [23, 24]. The ORF3 gene of attenuated vaccine isolates has a continuous deletion of 17 amino acids (aa 82-99), thus distinguishing the vaccine isolates from variant PEDV [24]. Therefore, the ORF3 gene has been the focus of molecular epidemiology PEDV studies [16, 20, 21, 25]. As aforementioned, we chose the S1 and ORF3 genes as the target genes for phylogenetic analysis.

Phylogenetic analysis of variations in the S1 gene of isolates collected in China distinguished the PEDV genotypes G1 and G2, including 1a classical PEDV, 1b classical PEDV, 2a circulating PEDV and $2 \mathrm{~b}$ circulating PEDV subgroups [26]. Based on the ORF3 gene, the phylogenetic analysis of PEDV isolates in China manifested in genotypes G1 and G2, the G2 genotype including 2a PEDV and 2b PEDV subgroups [27]. To investigate further infectivity, genetic diversity and molecular epidemiology of PEDV, we performed phylogenetic analyses based on the S1 and ORF3 genes of the latest Chinese isolates collected. In this study, 129 samples were obtained from 67 farms in 17 cities of central China, and the S1 and ORF3 genes of 21 representative field strains from 21 farms in 11 cities were sequenced and analysed.

\section{Methods \\ Sample collection and cDNA synthesis}

In this study, 129 intestinal tissue samples from new-born piglets suffering from severe diarrhea were collected from 67 farms in 17 cities (Zhengzhou, Kaifeng, Anyang, Hebi, Puyang, Xinxiang, Luoyang, Nanyang, Pingdingshan, Sanmenxia, Luohe, Jiaozuo, Xuchang, Yuncheng, Zhoukou, Zhumadia, and Xinyang) of central China from July 2014 to July 2015. Samples were diluted with 5 volumes of $0.9 \%$ saline $(w / v)$, frozen and thawed three times and then clarified by centrifugation for $5 \mathrm{~min}$ at $3000 \mathrm{rpm}$. Three hundred microliters of the supernatants were used for RNA extraction using TRIzol, dissolved in RNase-free water and then stored at $-80{ }^{\circ} \mathrm{C}$ until further use. Synthesis of the cDNA was carried out through reverse transcription as described below. A total of $13 \mu \mathrm{l}$ of viral RNA (approximately $1 \mu \mathrm{g}$ ) was mixed with $1 \mu \mathrm{l}$ of 10 pmol Oligo (dT) primer (TaKaRa), incubated at $70{ }^{\circ} \mathrm{C}$ for $10 \mathrm{~min}$, then placed on ice for $1 \mathrm{~min}$. Next, $4 \mu \mathrm{l}$ of $5 \times$ RT buffer, $1 \mu \mathrm{l}$ of dNTP $(2.5 \mathrm{mM})$ mixture, $0.5 \mu \mathrm{l}$ of RNase inhibitor $(40 \mathrm{U} / \mu \mathrm{l})$ and $0.5 \mu \mathrm{l}$ of reverse transcriptase

Table 1 Primers used in this study

\begin{tabular}{llll}
\hline Primer name & Nucleotide sequence, 5'-3' & Size(bp) & Primer location ${ }^{2}$ \\
\hline PEDV-F & TTTATTCTGTCACGCCAT & 197 & $2,2709-22,726$ \\
PEDV-R & AGATTACAAACACCTATGTTA & & $22,884-22,905$ \\
S1U1-F & GGTAAGTTGCTAGTGCGTAA & 1461 & $20,570-20,589$ \\
S1U1-R & CAGGATCATCACAATAAAGAA & & $22,010-22,030$ \\
S1U2-F & TITCTGGACCATAGCATC & 1117 & $21,939-21,956$ \\
S1U2-R & AGCACAATCAACACTAAC & & $23,038-23,055$ \\
ORF3-F & TCCTAGACTTCAACCTTACG & 833 & $24,741-24,760$ \\
ORF3-R & GGTGACAAGTGAAGCACAGA & & $25,551-25,570$ \\
\hline
\end{tabular}

${ }^{a}$ In relation to the genome of PEDV CV777 strain (AF353511) 
M-MLV (200 U/ $\mu \mathrm{l})$ were added and gently mixed. The mixture was kept at $42{ }^{\circ} \mathrm{C}$ for $1 \mathrm{~h}$ and the resulting cDNA stored at $-20{ }^{\circ} \mathrm{C}$ until further use.

\section{Clinical samples detection}

Primers used in this study were designed to target the conserved regions of the $\mathrm{S}$ gene and were synthesised by
Sangon Biotech. The primers are listed in Table 1. For the PCR reactions, $1 \mu \mathrm{l}$ of cDNA, $10 \mu \mathrm{l}$ ExTaq DNA polymerase (TAKARA), $1 \mu \mathrm{l}$ of each primer $(10 \mathrm{pmol})$ and RNase-free water in a total volume of $20 \mu \mathrm{l}$. The amplification was carried out as follows: $95^{\circ} \mathrm{C}$ for $5 \mathrm{~min}$, followed by 33 cycles of $95^{\circ} \mathrm{C}$ for $1 \mathrm{~min}, 57^{\circ} \mathrm{C}$ for $1 \mathrm{~min}$ and $72{ }^{\circ} \mathrm{C}$ for $1 \mathrm{~min}$ and finally $72{ }^{\circ} \mathrm{C}$ for $10 \mathrm{~min}$. The

Table 2 Reference strains used in this study

\begin{tabular}{|c|c|c|c|c|}
\hline Reference strains & Countries & S gene(nt) & ORF3 gene(nt) & Accession no. \\
\hline CV777 & Belgium,1978 & 2367 & 675 & AF353511.1 \\
\hline CV777 attenuated & China, 1998 & 2364 & 276 & KT323979.1 \\
\hline DR13/virulent & Korea,1999 & 2367 & 675 & JQ023161.1 \\
\hline $\mathrm{CH} / Z M D Z Y / 11$ & China,2011 & 2376 & 675 & KC196276.1 \\
\hline LZC & China/Gansu, $<2006$ & 2367 & 675 & EF185992.1 \\
\hline SM98 & Korea,1998 & 2379 & 675 & GU937797.1 \\
\hline MN & USA,2013 & 2376 & 675 & KF468752.1 \\
\hline$|A|$ & USA,2013 & 2376 & 675 & KF468753.1 \\
\hline IA2 & USA,2013 & 2376 & 675 & KF468754.1 \\
\hline DR13/attenuated & Korea,2003 & 2364 & 276 & JQ023162 \\
\hline SD-M & China/Shandong,2012 & 2364 & 276 & JX560761 \\
\hline GD-A & China/Guangdong,2012 & 2376 & 675 & JX112709 \\
\hline $\mathrm{CH} / \mathrm{S}$ & China/Shanghai,1986 & 2367 & 675 & JN547228 \\
\hline TC PC177-P2 & USA,2013 & 1785 & 675 & KM392229 \\
\hline BJ-2011-1 & China/Beijing,2011 & 2376 & 675 & JN825712 \\
\hline $\mathrm{AH} 2012$ & China/Anhui,2012 & 2376 & 675 & KC210145 \\
\hline AJ1102 & China/Hubei,2011 & 2376 & 675 & JX188454 \\
\hline $83 P-5$ & Japan1983 & 2364 & - & AB548621 \\
\hline CH/JX-1/2013 & China/Jiangxi,2013 & 2376 & 675 & KF760557 \\
\hline $\mathrm{CH} / \mathrm{JX}-2 / 2013$ & China/Jiangxi,2013 & 2376 & 675 & KJ526096 \\
\hline $\mathrm{Brl} / 87$ & France, 1987 & 2367 & - & Z25483 \\
\hline HN1303 & China/Luoyang,2013 & 2376 & - & KR080551 \\
\hline $\mathrm{CH} / \mathrm{FCH}-01$ & China,2013 & - & 675 & KF476054(O) \\
\hline $\mathrm{CH} / \mathrm{JCH}$ & China,2013 & - & 675 & KF476059(O) \\
\hline $\mathrm{CH} / \mathrm{KF}-01$ & China,2013 & - & 675 & KF476051(O) \\
\hline $\mathrm{CH} / \mathrm{XIP}-03$ & China,2013 & - & 675 & KF476058(O) \\
\hline 13-019349 & USA,2013 & 2376 & 675 & KF267450.1 \\
\hline Chinju99 & Korea,2009 & - & 675 & EU792474.1(O) \\
\hline CH/HLJHH-2/2011 & China,2012 & - & 675 & JQ305099.1(O) \\
\hline MK & Japan,2013 & 2367 & 675 & AB548624.1(cS) \\
\hline AD01 & Korea,2013 & 2376 & - & KC879280.1(cS) \\
\hline $\mathrm{CH} / \mathrm{HNZZ/2011}$ & China,2011 & 2364 & - & JN601050(S1) \\
\hline CH/FJXM-1/2012 & China,2012 & 2376 & - & JX070671 \\
\hline MYG-1/JPN/2014 & Japan,2014 & 1794 & - & LC063838.1 \\
\hline TTR-2/JPN/2014 & Japan,2014 & - & 252 & LC063828.1 \\
\hline $\mathrm{OH} 851$ & USA,2014 & 2367 & 675 & KJ399978.1 \\
\hline $\mathrm{SH} / 2015 / 124$ & China,2015 & 2376 & 675 & KU710245.1(S1), KU641672.1(ORF3) \\
\hline
\end{tabular}


products were examined by electrophoresis using a 1.0\% agarose gel.

\section{Sequencing of the S1 and ORF3 genes}

The S1 and ORF3 genes of 21 representative field strains from 21 farms in 11 cities (Kaifeng, Anyang, Hebi, Puyang, Xinxiang, Luoyang, Nanyang, Sanmenxia, Xuchang, Yuncheng and Zhumadian) were amplified by PCR. To obtain the complete S1 (1-789 aa) sequence, four primers (S1U1F, S1U1R, S1U2F and S1U2R) were designed and synthesised as previously described [28-30] according to Table 1, and the length of the final fragment was $2367 \mathrm{bp}$. The full-length ORF3 gene was obtained using previously published primers, and the length of the PCR product was $833 \mathrm{bp}$ [31]. PCR products were purified, subcloned into pMD19-T and transformed using DH5 $\alpha$ competent cells. The reagents were purchased from TaKaRa. Triplicate recombinant DNA positive clones from each PEDV isolate were sequenced by Sangon Biotech, China.

\section{Multiple sequence alignments and phylogenetic analysis} The complete S1 gene (2367 bp) was obtained through the sequence matching of S1U1 and S1U2 with flanking sequences removed. Sequences of S1 and ORF3 were processed by the Clustal W method through the DNAMAN 8 software, and phylogenetic trees were constructed by the neighbor-joining method using MEGA 6 software. Bootstrap values were indicated for each node from 1000 replicates. In addition, 37 reference strains (Table 2) were chosen from Genbank for inclusion in the phylogenetic analysis.

\section{Results \\ PEDV detection}

PEDV were detected by PCR on $94.03 \%$ (63 of 67) pig farms in 17 cities, and $92.25 \%$ (119 of 129) of samples were positive for PEDV in clinical diseased samples.

\section{Phylogenetic analysis of the S1 gene}

According to the phylogenetic analysis of the S1 gene, 21 PEDV isolates in this study (Table 3) were all subtype G2 and were distributed in two subgroups: 2a circulating PEDV and $2 b$ circulating PEDV (Fig. 1a). Our isolates showed a close relationship to some isolates from China (CH/ZMDZY/11, HN1303, AJ1102, et al.), Korea (AD01) and American (MN, IA1, IA2, 13-019349); however, our isolates differed from isolates collected previously from China (LZC, CH/HNZZ/2011, and SD-M), Korea (SM98), Japan (83-P5 and MK) and the vaccine strain CV777attenuated (used in China) and DR13 (used in Korea) which showed similar to the phylogenetic trees based on the sequences of amino acid (see Additional file 1: Figure

Table 3 The PEDV field strains used in this study

\begin{tabular}{|c|c|c|c|c|c|}
\hline Field strains & Origin & S gene(nt) & Accession no. & ORF3 gene(nt) & Accession no. \\
\hline $\mathrm{CH} / \mathrm{HNHB}-1$ & Hebi, Henan & 2376 & KU977480 & 675 & KU977501 \\
\hline $\mathrm{CH} / \mathrm{HNHB}-2$ & Hebi, Henan & 2376 & KU977481 & 675 & KU977502 \\
\hline $\mathrm{CH} / \mathrm{HNHB}-3$ & Hebi, Henan & 2376 & KU977482 & 675 & KU977503 \\
\hline $\mathrm{CH} / \mathrm{HNHB}-4$ & Hebi, Henan & 2376 & KU977483 & 675 & KU977504 \\
\hline $\mathrm{CH} / \mathrm{HNHB}-5$ & Hebi, Henan & 2376 & KU977484 & 675 & KU977505 \\
\hline $\mathrm{CH} / \mathrm{HNHB}-6$ & Hebi, Henan & 2376 & KU977485 & 675 & KU977506 \\
\hline $\mathrm{CH} / \mathrm{HNHB}-7$ & Hebi, Henan & 2376 & KU977486 & 675 & KU977507 \\
\hline $\mathrm{CH} / \mathrm{HNKF}-1$ & Kaifeng, Henan & 2376 & KU977487 & 675 & KU977508 \\
\hline $\mathrm{CH} / \mathrm{HNKF}-2$ & Kaifeng, Henan & 2376 & KU977488 & 675 & KU977509 \\
\hline $\mathrm{CH} / \mathrm{HNKF}-3$ & Kaifeng, Henan & 2376 & KU977489 & 675 & KU977510 \\
\hline $\mathrm{CH} / \mathrm{HNSMX}$ & Sanmenxia, Henan & 2376 & KU977490 & 675 & KU977511 \\
\hline $\mathrm{CH} / \mathrm{SXYC}$ & Yuncheng, Shanxi & 2376 & KU977491 & 675 & KU977512 \\
\hline $\mathrm{CH} / \mathrm{HNXC}$ & Xuchang, Henan & 2376 & KU977492 & 675 & KU977513 \\
\hline $\mathrm{CH} / \mathrm{HNXX}$ & Xinxiang, Henan & 2376 & KU977493 & 675 & KU977514 \\
\hline $\mathrm{CH} / \mathrm{HNAY}$ & Anyang, Henan & 2376 & KU977494 & 675 & KU977515 \\
\hline CH/HNNY-1 & Nanyang, Henan & 2376 & KU977495 & 675 & KU977516 \\
\hline $\mathrm{CH} / \mathrm{HNNY}-2$ & Nanyang, Henan & 2376 & KU977496 & 675 & KU977517 \\
\hline $\mathrm{CH} / \mathrm{HNNY}-3$ & Nanyang, Henan & 2376 & KU977497 & 675 & KU977518 \\
\hline $\mathrm{CH} / \mathrm{HNZMD}$ & Zhumadian, Henan & 2376 & KU977498 & 675 & KU977519 \\
\hline $\mathrm{CH} / \mathrm{HNLY}$ & Luoyang, Henan & 2382 & KU977499 & 675 & KU977520 \\
\hline $\mathrm{CH} / \mathrm{HNPY}$ & Puyang, Henan & 2376 & KU977500 & 675 & KU977521 \\
\hline
\end{tabular}




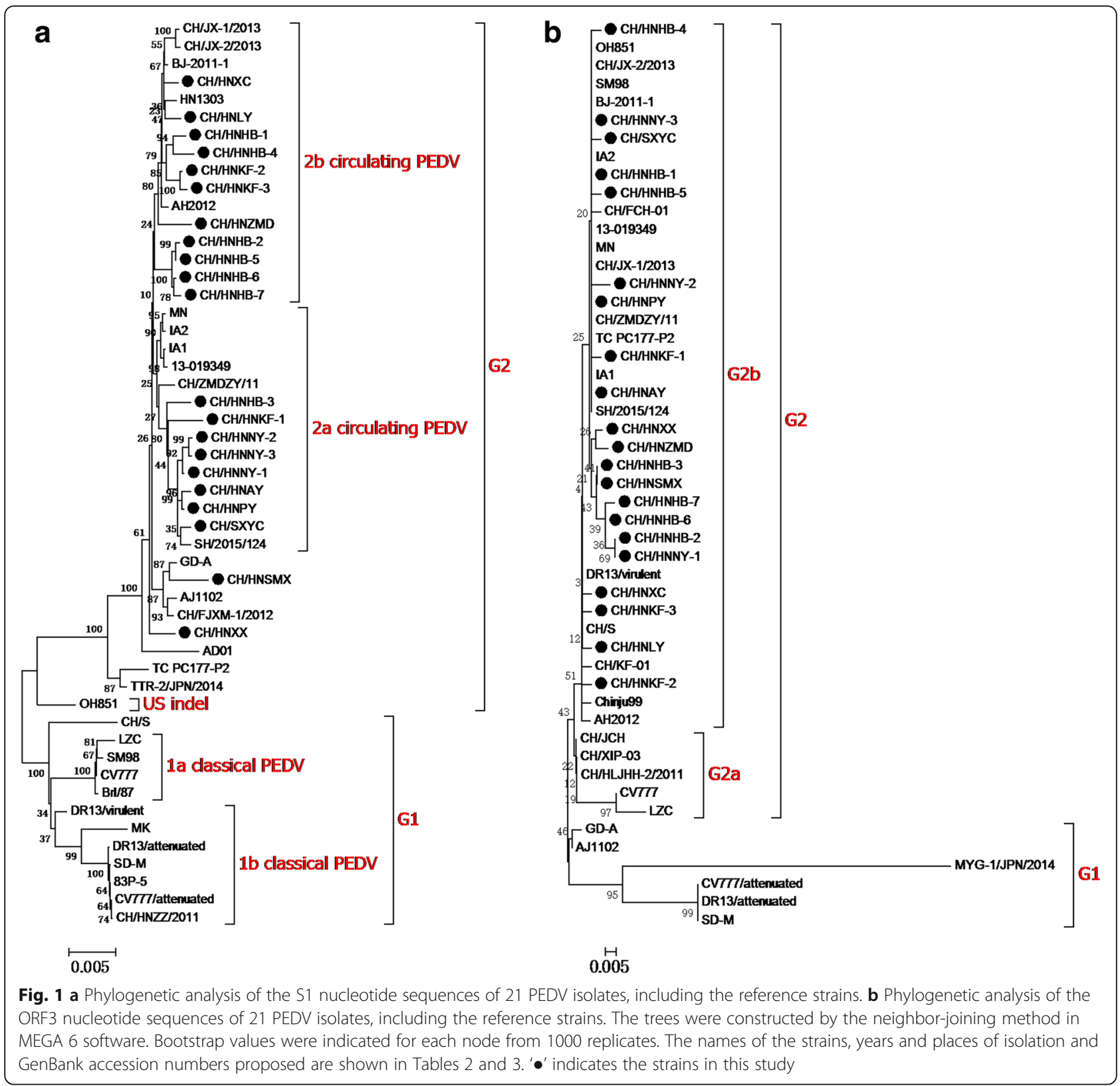

S1). According to the sequences of S1 genes processed by DNAMAN 8 software, our isolates exhibited 92.1-92.7\% nucleotide identity and $89.7-91.2 \%$ amino acid identity compared with the CV777 strain. Meanwhile, our isolates exhibited 91.4-92.0\% nucleotide identity and 89.1-90.7\% amino acid identity compared with the CV777 attenuated strain.

According to the predicted amino acid sequence of S1 genes in this study, we found one novel PEDV variant, CH/HNLY, that had 4-aa substitution at position $375,{ }^{\mathrm{RSSS}} 375^{\mathrm{T}}$ and a single deletion at position 430 (Fig. 2). Correspondingly, at the nucleotide level, CH/HNLY had 9-nt (GGTCGTCGT) insertion between positions 1123
(A) and 1124 (T) and 3-nt (GAT) deletion between positions $1283(\mathrm{C})$ and $1287(\mathrm{G})$.

We also examined the three major epitope regions, viz : aa 498-637, aa 747-754 and aa 763-770. The sequences at aa 747-754 were conserved between the latest Chinese PEDV isolates and CV777 attenuated strain, however the sequences at positions 498-637 and 763-770 were variable (Table 4 ).

\section{Phylogenetic analysis of the ORF3 gene}

According to the analysis of the ORF3 genes, 21 PEDV isolates in this study (Table 3) were all subtype G2 and were distributed in subgroup G2b which showed similar 


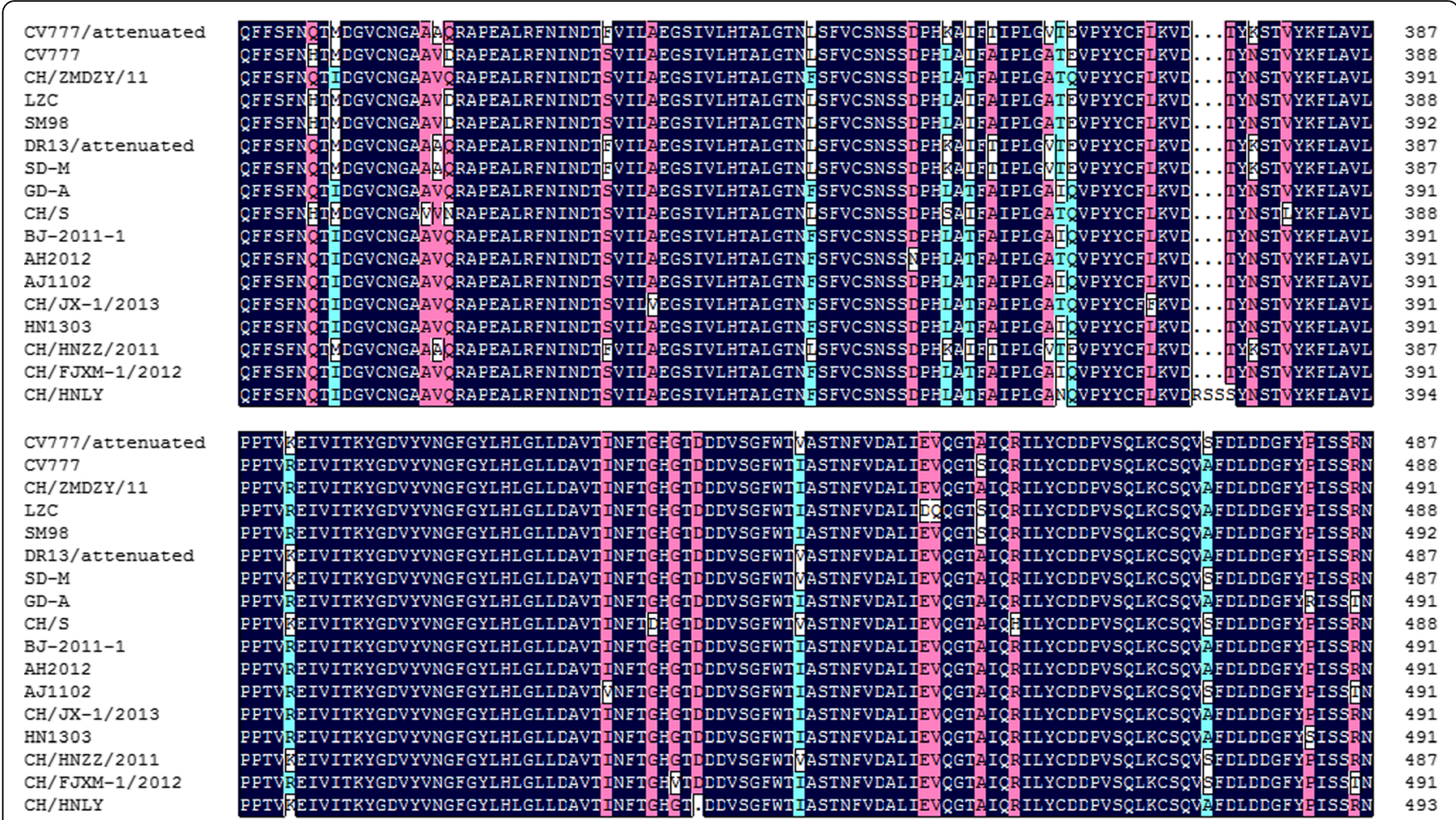

Fig. 2 CV777/attenuated as the reference strain and the amino acid sequence of CH/HNLY, with 4-aa insertion/deletion (RSSS/T) at position 375 and 1-aa (D) deletion at position 430 (CV777 attenuated strain accession number: KT323979.1) are indicated

to the phylogenetic trees based on the sequences of amino acid (see Additional file 2: Figure S2); in addition, our strains showed a close relationship to published isolates and genetically differed from the vaccine strains which were all subtype G1 (Fig. 1b), indicating that the prevailing PEDV strains were mostly variants. According to the sequences of ORF3 genes processed by DNAMAN 8 software, our isolates exhibited 95.996.9\% nucleotide identity and $93.8-96.4 \%$ amino acid identity compared with the CV777 strain. Meanwhile, our isolates exhibited 91.3-93.1\% nucleotide identity and $84.6-89 \%$ amino acid identity compared with the CV777 attenuated strain.

\section{Discussion}

Previous studies found that $79.66 \%$ of pig farms in 29 provinces to be positive for the presence of PEDV, with $72.27 \%$ of samples confirmed as PEDV-positive [16]. In the present study, $94.03 \%$ (63 of 67) of pig farms in 17 cities, 92.25\% (119 of 129) samples, were PEDV-positive, indicating a high prevalence of PEDV in clinical diseased samples.

The $S$ gene might correlate with PEDV pathogenicity [4]. The S1 domain of the S protein is the major target for PEDV vaccine development [32]. Our previous report suggested that the amino acid changes in the S1 domain might be associated with a change in antigenicity [20]. Extensive variation of the $\mathrm{S}$ protein has been reported earlier $[17,33]$. In this study, we found that in the three major epitope regions, the amino acid sequence at aa 748-755 was conserved, whereas aa 499-638 and aa 764-771 were variable. Accordingly, within the S1 domain of the $\mathrm{S}$ protein, the series of single amino acid substitutions found were: ${ }^{\mathrm{S}} 516^{\mathrm{A}},{ }^{\mathrm{S}} 548^{\mathrm{T}},{ }^{\mathrm{S}} 593^{\mathrm{G}},{ }^{\mathrm{E}} 632^{\mathrm{Q}}, \mathrm{S}_{763^{\mathrm{L}}}$ and ${ }^{S} 765^{\mathrm{D}}$. These changes were found in the strain $\mathrm{CH} /$ ZMDZY/11 that was previously isolated in central China [34]. However, as shown in Table 4, there were other single aa mutations, suggesting that the gene encoding the antigenic domain of S1 may constantly vary. According to the phylogenetic analysis, our isolates were all subtype G2 (Fig. 1a) and mostly further divided into two subgroups, 2a circulating PEDV and $2 \mathrm{~b}$ circulating PEDV. We have shown that the S1 domain of isolates differed genetically from the classical PEDV, but the isolates were similar to previously reported isolates from eastern, north western and southern China [35-37], which might be the reason why the currently existing vaccine is inefficient.

In this study, we detected one novel PEDV variant, $\mathrm{CH} / \mathrm{HNLY}$, with mutations at positions 375 and 430 $\left({ }^{\mathrm{RSSS}} 375^{\mathrm{T}}\right.$ and deletion at aa $430^{\mathrm{D}}$ ), which are located on the receptor binding domain (aa 253-638) for pAPN $[15,38]$. The phylogenetic analysis of nucleotide variation demonstrated that $\mathrm{CH} / \mathrm{HNLY}$ was related to $2 \mathrm{~b}$ circulating PEDV. It was reported that the classical PEDV exhibited weaker sugar-binding activity compared with the field isolate variant [39]. Reports have also found amino acid 
Table 4 Analysis of amino acid mutations in epitopes domains of field strains and the CV777 attenuated vaccine strain (aa 498-637, aa 747-754 and aa 763-770 located in CV777 attenuated)

\begin{tabular}{|c|c|c|c|c|c|c|c|c|c|c|c|c|c|c|c|c|c|c|c|c|c|c|c|c|c|c|c|c|c|}
\hline Strains & 499 & 500 & 514 & 516 & 520 & 522 & 526 & 530 & 543 & 548 & 561 & 572 & 583 & 587 & 590 & 593 & 604 & 607 & 608 & 611 & 632 & 634 & 636 & 751 & 762 & 763 & 765 & 766 & 768 \\
\hline CV777 attenuated & T & $L$ & S & A & $\mathrm{H}$ & G & 1 & T & R & $\mathrm{T}$ & S & K & K & S & L & G & E & S & G & $\mathrm{F}$ & Q & V & D & G & $P$ & L & D & G & V \\
\hline CV777 & & & & & L & $S$ & V & & & & & & & & & & A & & & L & E & 1 & & & & $S$ & Y & & \\
\hline $\mathrm{CH} / Z M D Z Y / 11$ & & & & S & $\mathrm{R}$ & & $\mathrm{T}$ & & & S & & & N & & & S & & & & & E & & & & & S & S & & \\
\hline $\mathrm{CH} / \mathrm{HNHB}-1$ & $\mathrm{D}$ & & & S & & & & & & S & & & & & & S & & & & & E & & & & & S & $S$ & & \\
\hline $\mathrm{CH} / \mathrm{HNHB}-2, \mathrm{CH} / \mathrm{HNHB}-5$ & & & A & S & & & & & & S & & & & & & S & $\mathrm{D}$ & & S & & $\mathrm{E}$ & & & & & S & s & & \\
\hline $\mathrm{CH} / \mathrm{HNHB}-3$ & & $P$ & & S & & & & & & S & & & & & & S & & & & & E & & & & & S & S & D & \\
\hline $\mathrm{CH} / \mathrm{HNHB}-4$ & A & & & S & & & & & & $S$ & & N & & & & S & & & & & E & & & & & S & S & & \\
\hline $\mathrm{CH} / \mathrm{HNHB}-6, \mathrm{CH} / \mathrm{HNHB}-7$ & & & A & S & & & & & & $S$ & & & & & & S & $\mathrm{D}$ & & & & $\mathrm{E}$ & & & & & S & S & & \\
\hline $\mathrm{CH} / \mathrm{HNKF}-1, \mathrm{CH} / \mathrm{HNLY}$ & & & & s & & & & & & $\mathrm{s}$ & & & & & & $\mathrm{s}$ & & & & & $\mathrm{E}$ & & & & & s & S & & \\
\hline $\mathrm{CH} / \mathrm{HNKF}-2$ & & & & S & & & & & & $S$ & Y & & & & & S & & & & & E & & & & & $S$ & $S$ & & \\
\hline $\mathrm{CH} / \mathrm{HNKF}-3$ & & & & S & & & & & & S & Y & & & & $P$ & S & & & & & $\mathrm{E}$ & & & & & S & S & & \\
\hline $\mathrm{CH} / \mathrm{HNSMX}$ & & & & & & & & & & $\mathrm{S}$ & & & & $\mathrm{T}$ & & S & & & & & $E$ & & G & & & S & S & & \\
\hline $\mathrm{CH} / \mathrm{SXYC}$ & & & & S & & & & A & & S & & & & & & S & & & & & $E$ & & & & & S & S & & \\
\hline $\mathrm{CH} / \mathrm{HNXC}$ & & & & S & & & & & & S & & & & & & S & & & & & V & & & & & S & S & & \\
\hline $\mathrm{CH} / \mathrm{HNXX}$ & & & & S & & & & & & $S$ & & & & & & S & & & V & & E & & & & & S & S & & \\
\hline $\mathrm{CH} / \mathrm{HNAY}$ & A & & & S & Y & & & & & S & & & & & & S & & & & & E & & & & L & S & S & & \\
\hline $\mathrm{CH} / \mathrm{HNNY}-1, \mathrm{CH} / \mathrm{HNNY}-2, \mathrm{CH} / \mathrm{HNNY}-3$, & & & & S & Y & & & & & S & & & & & & S & & & & & E & & & & & S & S & & \\
\hline $\mathrm{CH} / \mathrm{HNZMD}$ & & & & S & & & & & & $S$ & & $\mathrm{H}$ & & & & S & & & V & & E & & & & & S & $S$ & & A \\
\hline $\mathrm{CH} / \mathrm{HNPY}$ & $A$ & & & S & Y & & & & & s & & & & & & S & & & & & $\mathrm{E}$ & & & & L & S & s & & \\
\hline
\end{tabular}


substitutions in the receptor-binding region [27]. Whether or not these changes affect the biological functions of PEDV will require further investigation.

The ORF3 gene is highly relevant to the virulence of PEDV [23, 40], since it regulates virus production [13]. The ORF3 genes of the PEDV isolates in this study and other isolates did not show the large deletion characteristic of the vaccine CV777 strain. According to the phylogenetic analysis of ORF3, the 21 PEDV isolates in this study were divided into subtype G2 (Fig. 1b). The ORF3 gene analysis not only suggested that the isolates in central China were not only vaccine-unrelated, but the presence of multiple, distinct mutations indicated there is widespread diversity in this virulence gene. However, further studies are needed to clarify whether the virulence is change among these PEDV strains.

Phylogenetic analysis of both the S1 and ORF3 genes showed that our isolates exhibited high similarity to variant reference strains and differed from CV777. Phylogenetic analysis of ORF3 did not reveal differences between our isolates and partial classical PEDV strains which was similar to other report [27]. Further studies are required to clarify the biological functions among PEDV phylogenetic groups.

\section{Conclusions}

In conclusion, our study highlighted the present landscape of PEDV in central China, and the isolated strains in this study were all variable and genetically diverse. These findings make it clear that a new vaccine is required to control this disease. In addition, the discovery of a novel strain, $\mathrm{CH} / \mathrm{HNLY}$, provides an avenue for future investigations into the biological functions of PEDV.

\section{Additional files}

Additional file 1: Figure S1. Phylogenetic analysis of the S1 amino acid sequences of 21 PEDV isolates, including the reference strains. The trees were constructed by the neighbour-joining method in MEGA 6. Bootstrap values were indicated for each node from 1000 replicates. The names of the strains, years and places of isolation and GenBank accession numbers proposed are shown in Tables 2 and 3. ' $\bullet$ ' indicates the strains in this study. The phylogenetic analysis of CH/HNLY (with 4-aa insertion/ deletion (RSSS/T) at position 375 and 1-aa (D) deletion at position 430) was showed. (TIF $2238 \mathrm{~kb}$ )

Additional file 2: Figure S2. Phylogenetic analysis of the ORF3 amino acid sequences of 21 PEDV isolates, including the reference strains. The trees were constructed by the neighbour-joining method in MEGA 6. Bootstrap values were indicated for each node from 1000 replicates. The names of the strains, years and places of isolation and GenBank accession numbers proposed are shown in Tables 2 and 3 . ' $^{\prime}$ ' indicates the strains in this study. (TIF $1880 \mathrm{~kb}$ )

\section{Acknowledgments}

The authors would like to thank professor Gregson, London University, for revising the paper and thank Guangxu Xing, for processing data and revising the manuscript.

\section{Funding}

The work was supported by grants from National Key R\&D Program (2016YFD0500704), Major Program of Science and Technology in Henan (No.141100110100) and Program of Henan finance (No.201678-24).

\section{Authors' contributions}

YSu, YL, and YC designed experiments; YSu, BZ, PJ, DJ, CL, YSong, GW, and DL carried out experiments; YSu, YL and GX analyzed experimental results and analyzed sequencing data; $Y S u, Y L, R D$, and $G Z$ wrote the manuscript. All authors read and approved the final manuscript.

\section{Competing interests}

The authors declare that they have no competing interests.

\section{Ethics approval}

This work complied with the Ethical Standards of the Committee on Publication Ethics (COPE).

\section{Author details}

${ }^{1}$ College of Veterinary Medicine, Northwest Agriculture and Forestry University, Yangling, Shaanxi 712100, China. ${ }^{2}$ Henan Provincial Key Laboratory of Animal Immunology, Henan Academy of Agricultural Science, Zhengzhou 450002, China. ${ }^{3}$ College of Animal Science and Veterinary Medicine, Henan Agricultural University, Zhengzhou 450002, China. ${ }^{4}$ Jiangsu Co-innovation Center for Prevention and Control of Important Animal Infectious Diseases and Zoonoses, Yangzhou 225009, China.

Received: 28 June 2016 Accepted: 10 November 2016

Published online: 25 November 2016

\section{References}

1. Pensaert MB, de Bouck P. A new coronavirus-like particle associated with diarrhea in swine. Arch Virol. 1978:58:243-7.

2. Takahashi K, Okada K, Ohshima K. An outbreak of swine diarrhea of a new-type associated with coronavirus-like particles in Japan. J Vet Sci. 1983;45:829-32

3. Puranaveja S, Poolperm $P$, Lertwatcharasarakul $P$, Kesdaengsakonwut $S$, Boonsoongnern A, Urairong $K$, et al. Chinese-like strain of porcine epidemic diarrhea virus, Thailand. Emerg Infect Dis. 2009;15:1112-5.

4. Martelli P, Lavazza A, Nigrelli AD, Merialdi G, Alborali LG. Epidemic of diarrhoea caused by porcine epidemic diarrhoea virus in Italy. Vet Rec. 2008:162:307-10.

5. Cima G. Viral disease affects U.S. pigs: porcine epidemic diarrhea found in at least 11 states. J Am Vet Med Assoc. 2013;243:30-1.

6. Sun RQ, Cai RJ, Chen YQ, Liang PS, Chen DK, Song CX. Outbreak of porcine epidemic diarrhea in suckling piglets, China. Emerg Infect Dis. 2012;18:161-3.

7. Bridgen A, Kocherhans R, Tobler K, Carvajal A, Ackermann M. Further analysis of the genome of porcine epidemic diarrhoea virus. Adv Exp Med Biol. 1998;440:781-6.

8. Kocherhans R, Bridgen A, Ackermann M, Tobler K. Completion of the Porcine Epidemic Diarrhoea Coronavirus (PEDV) genome sequence. Virus Genes. 2001;23:137-44.

9. Duarte M, Tobler K, Bridgen A, Rasschaert D, Ackermann M, Laude $\mathrm{H}$. Sequence analysis of the porcine epidemic diarrhea virus genome between the nucleocapsid and spike protein genes reveals a polymorphic ORF. Virology. 1994;198:466-76.

10. Baudoux P, Carrat C, Besnardeau L, Charley B, Laude H. Coronavirus pseudoparticles formed with recombinant $\mathrm{M}$ and $\mathrm{E}$ proteins induce alpha interferon synthesis by leukocytes. J Virol. 1998:72:8636-43.

11. Curtis KM, Yount B, Baric RS. Role of nucleotides immediately flanking the transcription-regulating sequence core in coronavirus subgenomic mRNA synthesis. J Virol. 2002;76:1422-34.

12. Brian DA, Baric RS. Coronavirus genome structure and replication. Curr Top Microbiol Immunol. 2005;287:1-30.

13. Wang K, Lu W, Chen J, Xie S, Shi H, Hsu H, et al. PEDV ORF3 encodes an ion channel protein and regulates virus production. FEBS Lett. 2012;586:384-91.

14. Li F. Receptor recognition mechanisms of coronaviruses: a decade of structural studies. J Virol. 2015:89:1954-64.

15. Deng F, Ye G, Liu Q, Navid MT, Zhong X, Li Y, et al. Identification and comparison of receptor binding haracteristics of the spike protein of two porcine pidemic diarrheavirus strains. Viruses. 2016; doi: 10.3390/v8030055 
16. Chen J, Liu X, Shi D, Shi H, Zhang X, Li C, et al. Detection and molecular diversity of spike gene of porcine epidemic diarrhea virus in China. Viruses. 2013;5:2601-13.

17. Suzuki T, Murakami S, Takahashi O, Kodera A, Masuda T, Itoh S, et al. Molecular characterization of pig epidemic diarrhoea viruses isolated in Japan from 2013 to 2014. Infect Genet Evol. 2015:36:363-8.

18. Chang SH, Bae JL, Kang TJ, Kim J, Chung GH, Lim CW, et al. Identification of the epitope region capable of inducing neutralizing antibodies against the porcine epidemic diarrhea virus. Mol Cells. 2002;14:295-9.

19. Sun D, Feng L, Shi H, Chen J, Cui $X$, Chen H, et al. Identification of two novel $B$ cell epitopes on porcine epidemic diarrhea virus spike protein. Vet Microbiol. 2008;131:73-81.

20. Li R, Qiao S, Yang Y, Su Y, Zhao P, Zhou E, et al. Phylogenetic analysis of porcine epidemic diarrhea virus (PEDV) field strains in central China based on the ORF3 gene and the main neutralization epitopes. Arch Virol. 2013;159:1057-65

21. Song D, Huang D, Peng Q, Huang T, Chen Y, Zhang T, et al. Molecular characterization and phylogenetic analysis of porcine epidemic diarrhea viruses associated with outbreaks of severe diarrhea in piglets in Jiangxi, China 2013. PLoS One. 2015;10:e0120310.

22. Wang $X$, Chen J, Shi D, Shi $H$, Zhang $X$, Yuan J, et al. Immunogenicity and antigenic relationships among spike proteins of porcine epidemic diarrhea virus subtypes G1 and G2. Arch Virol. 2016;161:537-47.

23. Park SJ, Song DS, Ha GW, Park BK. Cloning and further sequence analysis of the spike gene of attenuated porcine epidemic diarrhea virus DR13. Virus Genes. 2007;35:55-64.

24. Park SJ, Moon HJ, Luo Y, Kim HK, Kim EM, Yang JS, et al. Cloning and further sequence analysis of the ORF3 gene of wild- and attenuated-type porcine epidemic diarrhea viruses. Virus Genes. 2008;36:95-104.

25. Temeeyasen G, Srijangwad A, Tripipat T, Tipsombatboon P, Piriyapongsa J, Phoolcharoen W, et al. Genetic diversity of ORF3 and spike genes of porcine epidemic diarrhea virus in Thailand. Infect Genet Evol. 2014;21:205-13.

26. Huang YW, Dickerman AW, Piñeyro P, Li L, Fang L, Kiehne R, et al. Origin, evolution, and genotyping of emergent porcine epidemic diarrhea virus strains in the United States. MBio. 2013;4:e00737-13.

27. Wang E, Guo D, Li C, Wei S, Wang Z, Liu Q, Zhang B, Kong F, Feng L, Sun D. Molecular characterization of the ORF3 and S1 Genes of porcine epidemic diarrhea virus non S-INDEL strains in seven regions of China, 2015. PLoS One. 2016;11:e0160561. doi:10.1371/journal.pone.0160561.

28. Kim SY, Song DS, Park BK. Differential detection of transmissible gastroenteritis virus and porcine epidemic diarrhea virus by duplex RT-PCR. J Vet Diagn Invest. 2001;13:516-20.

29. Jung K, Chae C. Effect of temperature on the detection of porcine epidemic diarrhea virus and transmissible gastroenteritis virus in fecal samples by reverse transcription-polymerase chain reaction. J Vet Diagn Invest. 2004;16:237-9.

30. Song DS, Kang BK, Oh JS, Ha GW, Yang JS, Moon HJ, et al. Multiplex reverse transcription-PCR for rapid differential detection of porcine epidemic diarrhea virus, transmissible gastroenteritis virus, and porcine group A rotavirus. J Vet Diagn Invest. 2006;18:278-81.

31. Song DS, Yang JS, Oh JS, Han JH, Park BK. Differentiation of a Vero cell adapted porcine epidemic diarrhea virus from Korean field strains by restriction fragment length polymorphism analysis of ORF3. Vaccine. 2003;21:1833-42.

32. Oh J, Lee KW, Choi HW, Lee C. Immunogenicity and protective efficacy of recombinant $\mathrm{S} 1$ domain of the porcine epidemic diarrhea virus spike protein. Arch Virol. 2014;159:2977-87.

33. Oka T, Saif LJ, Marthaler D, Esseili MA, Meulia T, Lin CM, et al. Cell culture isolation and sequence analysis of genetically diverse US porcine epidemic diarrhea virus strains including a novel strain with a large deletion in the spike gene. Vet Microbiol. 2014;173:258-69.

34. Wang XM, Niu BB, Yan H, Gao DS, Yang X, Chen L, et al. Genetic properties of endemic Chinese porcine epidemic diarrhea virus strains isolated since 2010. Arch Virol. 2013;158:2487-94

35. Chen X, Yang J, Yu F, Ge J, Lin T, Song T. Molecular characterization and phylogenetic analysis of porcine epidemic diarrhea virus (PEDV) samples from field cases in Fujian, China. Virus Genes. 2012;45:499-507.

36. Tian Y, Yu Z, Cheng K, Liu Y, Huang J, Xin Y, et al. Molecular characterization and phylogenetic analysis of new variants of the porcine epidemic diarrhea virus in Gansu, China in 2012. Viruses. 2013:5:1991-2004.
37. Li ZL, Zhu L, Ma JY, Zhou QF, Song YH, Sun BL, et al. Molecular characterization and phylogenetic analysis of porcine epidemic diarrhea virus (PEDV) field strains in south China. Virus Genes. 2012:45:181-5.

38. Liu C, Tang J, Ma Y, Liang X, Yang Y, Peng G, et al. Receptor usage and cell entry of porcine epidemic diarrhea coronavirus. J Virol. 2015;89:6121-5.

39. Deng F, Ye G, Liu Q, Navid MT, Zhong X, Li Y, Wan C, Xiao S, He Q, Fu ZF, Peng $\mathrm{G}$. Identification and comparison of receptor binding characteristics of the spike protein of two porcine epidemic diarrhea virus strains. Viruses. 2016:8:55. doi:10.3390/v8030055

40. Chen X, Zeng L, Yang J, Yu F, Ge J, Guo Q, et al. Sequence heterogeneity of the ORF3 gene of porcine epidemic diarrhea viruses field samples in Fujian, China, 2010-2012. Viruses. 2013;5:2375-83.

\section{Submit your next manuscript to BioMed Central and we will help you at every step:}

- We accept pre-submission inquiries

- Our selector tool helps you to find the most relevant journal

- We provide round the clock customer support

- Convenient online submission

- Thorough peer review

- Inclusion in PubMed and all major indexing services

- Maximum visibility for your research

Submit your manuscript at www.biomedcentral.com/submit
) Biomed Central 